\title{
GOVERNMENT CONTRACTS: COURT OF CLAIMS CIRGUMVENTS BIANGHI'S PROHIBITION OF DE NOVO REVIEW BY NARROW INTERPRETATION OF DISPUTES CLAUSE
}

$\mathbf{T}$ HE STANDARD disputes clause ${ }^{1}$ included in government procurement contracts provides an expeditious and inexpensive means of hearing disputes and settling claims without court action. ${ }^{2}$ The extent to which the disputes clause authorizes government agencies to make final determinations of fact binding upon subsequent adjudication has been considered the subject of a "continuing struggle"3 between the Supreme Court and the Court of Claims. In Utah Const. \& Mining Co. v. United States, ${ }^{4}$ the Court of Claims perpetuated this division by adopting a narrow interpretation of the scope of the disputes clause.

Prior to instituting the action in Utah, the contractor had applied to the contracting officer for an extension of time in which

1 " (a) Except as otherwise provided in this contract, any dispute concerning a question of fact arising under this contract which is not disposed of by agreement shall be decided by the Contracting Officer, who shall reduce his decision to writing and mail or otherwise furnish a copy thereof to the Contractor. The decision of the Contracting Officer shall be final and conclusive unless, within 30 days from the date of receipt of such copy, the Contractor mails or otherwise furnishes to the Contracting Officer a written appeal addressed to the head of the agency involved. The decision of the head of the agency or his duly authorized representative for the determination of such appeals shall be final and conclusive. This provision shall not be pleaded in any suit involving a question of fact arising under this contract as limiting judicial review of any such decision to cases where fraud by such official or his representative or board is alleged: Provided, however, that any such decision shall be final and conclusive unless the same is fraudulent or capricious or arbitrary or so grossly erroncous as necessarily to imply bad faith or is not supported by substantial evidence. In con. nection with any appeal proceeding under this clause, the Contractor shall be afforded an opportunity to be heard and to offer evidence in support of his appeal. Pending final decision of a dispute hereunder, the Contractor shall proceed diligently with the performance of the contract and in accordance with the Contracting Officer's decision.

(b) This Disputes clause does not preclude consideration of questions of law in connection with decisions provided for in paragraph (a) above. Nothing in this contract, however, shall be construed as making final the decision of any administrative official, representative, or board on a question of law." 4I C.F.R. $\$$ I-16.901-23A, cl. 6 (1964) (standard disputes clause in construction contracts). See 41 C.F.R. $\$$ 1-16.90132, cl. I2 (1964) (standard disputes clause in supply contracts).

${ }^{2}$ See Shedd, Disputes and Appeals: The Armed Services Board of Contract Appeals, 29 LAW \& Contemp. ProB. 39, 40 (1964).

shedd, supra note 2 , at 71 .

- 339 F.2d 606 (Ct. Cl. I964). 
to perform the contract due to alleged delays caused by the government. This request was denied by the contracting officer, and the Atomic Energy Commission's Advisory Board of Contract Appeals affirmed the decision, 5 making a specific finding that no delay was caused by the Government. The contractor subsequently instituted an action for breach of contract in the Court of Claims, requesting damages due to delay allegedly caused by the Government. ${ }^{6}$ The Court of Claims held that since the jurisdiction of the agency under the disputes clause is limited to questions of fact "arising under this contract,"7 the court was not bound to accept factual determinations made by the agency in a suit for breach of contract. ${ }^{8}$ Thus, the court received evidence de novo on the issue of delay.

In contrast with the approach suggested in Utah, the Supreme Court has traditionally taken a broad view of the disputes clause and the authority which it vests in the boards to render final decisions. Consistently applying private contract principles in its interpretation of the clause, 9 the Court has emphasized that the parties are competent to decide for themselves the manner in which disputes are to be decided.10 The Court's insistence on board finality culminated in Wunderlich $v$. United States ${ }^{11}$ in which the authority of the courts to review board decisions was limited to the determination of the existence of fraud. ${ }^{12}$ However, the scope of review of

\footnotetext{
$\checkmark$ About fourteen governmental departments and agencies have established boards to render final decisions or advisory opinions. In other agencies, the final decision is made by the head of the agency. See Miller, Administrative Determination and Judicial Review of Contract Appeals, 5 B.C. IND. \& CoMM. L. REv. 111, 116-17 (1963).

- This claim for damages for delay was only one of several claims presented in $U t a h$, but it posed the major problem confronting the court.

7339 F.2d at 610 .

I Ibid.

$\rightarrow \quad{ }^{\circ}$ Sce Shedd, supra note 2, at 43-44. In United States v. Moorman, 338 U.S. 457 (1950), the Supreme Court relied on an annotation involving the validity of contractual agreements binding the parties by the decision of architects or engineers under building or construction contracts. Id. at 462. Along witb many private contract cases, the annotation cited one government contract case. Annot., 54 A.L.R. 1255 (1928); cf. Martinsburg \& Potomac R.R. v. March, 114 U.S. 549 (1885) (private contract case wherein the Court relies on two government contract cases). Williston treats the cases involving government disputes clauses under the general classification of cases giving conclusive effect to architect's certificates. 3 Williston, ConTracts $\$ 798$ n.2 (rev. ed. 1936).

${ }^{10}$ See, e.g., United States v. Wunderlich, 342 U.S. 98, 100 (1951); United States v. Moorman, 338 U.S. 457, 461 (1950).

11342 U.S. 98 (1951).

12342 U.S. at 100 . The scope of judicial review was first defined by the Supreme Court in Kihlberg $v$. United States, when the Court said that the decision would be final "in the absence of fraud or such gross mistake as would necessarily imply bad faith, or a failure to exercise an honest judgment ..." 97 U.S. 398, 402 (1878). The
} 
agency determinations was subsequently expanded by Congress in the Wunderlich Act to encompass those cases in which the decision was "capricious or arbitrary or so grossly erroneous as necessarily to imply bad faith, or is not supported by substantial evidence."10 The Court of Claims construed this act to permit admission of evidence de novo in reviewing an agency's decision. ${ }^{14}$ But in United States $v$. Carlo Bianchi 8 Co., ${ }^{15}$ the Supreme Court limited the Court of Claims to an examination of the administrative record when it reviews a factual determination under the standards of the act.10

Nevertheless, there are well-recognized limitations on the adjudicative authority of the boards. Final factual determinations by the board are subject to the reviewing standards of the Wunderlich Act, and the act also expressly prohibits contractual provisions giving conclusive effect to decisions upon questions of law. ${ }^{17}$ Since the authority of the boards to decide disputes is purely contractual, the parties are bound only by the decision of "any dispute concerning a question of fact arising under this contract."18 Both the Court of Claims and the Boards have consistently recognized a distinction between disputes arising under the contract and disputes concerning an alleged breach of contract, ${ }^{18}$ and the Court of Claims has

Court of Claims subsequently attempted to liberalize the Kihlberg mandate. See the cases collected in Note, United States $v$. Carlo Bianchi \& Co.: Finality Under the Dis. putes Clause, 39 N.Y.U.L. REv. 290, 291 n.4 (1964).

${ }^{18} 68$ Stat. 81 (1954), 41 U.S.C. \$ 321 (1958).

1" See, e.g., Carlo Bianchi \& Co. v. United States, 144 Ct. Cl. 500, 506, 169 F. Supp. 514, 517 (1959), rev'd 373 U.S. 709 (1963); Volentine \& Littleton v. United States, 196 Ct. Cl. 638, 641-42, 145 F. Supp. 952, 954 (1956); Note, 52 GEO. L.J. 189, 191 (1963). 15373 U.S. 709 (1963).

${ }^{10}$ In Bianchi, the contractor sought a reversal of the board's decision on the ground that it was not supported by substantial evidence. Though styled by the Supreme Court as a breach of contract claim, it is clear that the contractor's claim for relief was based solely on his rights arising under the changed conditions article of the contract. He did not contend that the factual issue was beyond the scope of the disputes clause. 373 U.S. at 710-14.

In Utah, the contractor's claim for damages due to the government's delay was not predicated on a specific provision of the contract but on a general breach of the contract for which the board could not obtain jurisdiction. $339 \mathrm{~F} .2 \mathrm{~d}$ at 612 .

${ }^{17}$ Act of May 11, 1954 (Wunderlich Act) $\S 2,68$ Stat. 81, 41 U.S.C. $\S 322$ (1958). It has been held that interpretation of the meaning of a contractual provision is the resolution of a legal question and outside the scope of the disputes clause. See, e.g., Kayfield Const. Corp. v. United States, 278 F.2d 217, 218 (2d Cir. 1960); United States v. Lundstrom, I39 F.2d 792, 795 (9th Cir. 1943); Gerhardt F. Meyne Co. v. United States, 110 Ct. Cl. 527, 548, 76 F. Supp. 811, 814 (1948).

${ }^{18}$ See disputes clause cited note 1 supra.

${ }^{10}$ See, e.g., Continental Ill. Nat'1 Bank v. United States, 126 Ct. Cl. 631, 640, 115 F. Supp. 892, 897 (1953); Anthony P. Miller, Inc. v. United States, 111 Ct. Cl. 252, 390, 77 F. Supp. 209, 212 (1948); Phoenix Bridge Co. v. United States, 85 Ct. Cl. 603, 629-30 
decided that finality need not be accorded factual findings made by a board when it attempts to adjudicate a dispute which involves a breach of contract. ${ }^{20}$ The Utah decision goes a step farther by providing that even if a board's finding of fact is made incident to its decision of a dispute "arising under the contract," the Court of Claims need not consider it final in a subsequent action for breach of contract. ${ }^{21}$ This latest expression of the Court of Claims and several of its other post-Bianchi decisions ${ }^{22}$ illustrate an apparent effort by the court to inject into the Bianchi mandate more judicial participation.

The language of the disputes clause does not easily lend itself to resolution of the problem posed in $U t a h .^{23}$ Nor do the Wunderlich Act or the Bianchi decision afford much assistance. The act

(1937); 1 McBride \& Wachtel, Government Contracts $\$ \$ 6.220,6.220$ [9] (1965). For board decisions, see Shedd, supra note 2, at 73 n.108.

The number of cases which are deemed to involve breach of contract has been considerably reduced by the inclusion of contractual clauses which convert what would otherwise be breach of contract claims into "disputes arising under the contract." See Shedd, supra note 2, at 74 . It has been urged that the boards should broadly interpret these provisions to attain a jurisdiction parallel to that of the Court of Claims. Cuneo \& Crowell, Parallel Jurisdiction: If the Court of Claims Can, Why Not the Administrative Boards?, 33 FordhaM L. REv. 137, 138 (1964).

${ }^{20}$ See, e.g., Volentine \& Littleton v. United States, 144 Ct. Cl. 723, 726, 169 F. Supp. 263, 265 (1959); Railroad Waterproofing Corp. v. United States, 133 Ct. Cl. 911, 915-16, 137 F. Supp. 713, 715-16 (1956); Langevin v. United States, 100 Ct. Cl. 15, 30 (1943). Since Bianchi, the Court of Claims has indicated that it would follow the same interpretation. WPC Enterprises, Inc. v. United States, 323 F.2d 874, 878 (Ct. G1. 1963) (dictum); Stein Bros. Mfg. Co, v. United States, 337 F.2d 861, 862 (Ct. Cl. 1963) (dictum).

The Government, however, has contended since Bianchi that the Boards bave authority to render final decisions on all factual disputes even when related solely to issues of law. See Note, 39 N.Y.U.L. Rev. 290, 302 n.54 (1964) and accompanying text. This argument was made in Utah, Defendant's Supplementary Memorandum, pp. 12-13, but the Government recognized "that an argnment can be made that the disputes agreement encompasses only those disputes for which relief can be afforded by the contracting agency under specific provisions of the contract." Id. at 14 .

21339 F.2d at 612.

${ }_{22}$ In Stein Bros. Mfg. Co. v. United States, 337 F.2d 861, 862 (Ct. Cl. 1963) and WPC Enterprises, Inc. v. United States, 323 F.2d 874, 878 (Ct. Cl. 1963), the Court of Claims decided that the Bianchi requirement for an "administrative review" was evidentiary, and could be waived by not making a timely objection to the introduction of de novo evidence.

Furthermore, the court held that where the determination of the amount of recovery had not been an issue before the agency, that determination would be made by the Court of Claims whether the claim was one arising under the contract or was for breach of contract. Stein Bros. Mfg. Co. v. United States, supra at 863-64; see Note, United States $v$. Carlo Bianchi \& Co.: Finality Under the Disputes Clause, 39 N.Y.U.L. REv. 290, 297 nn. 37 \& 38 (1964).

${ }^{23}$ The disputes clause calls for the decision of "any dispute concerning a question of fact arising under this contract ...." See note I supra. That the clause is subject to varying interpretations is indicated by the different constructions placed on it by the majority and dissenting judges in Utah. See $339 \mathrm{~F} .2 \mathrm{~d}$ at 610,617 . 
recognizes the finality of decisions under the clause but is concerned with prescribing reviewing standards ${ }^{24}$ and not interpreting the scope of the clause. The Bianchi decision, dealing with the procedure of review, expressly recognized that no argnments were addressed to the scope of the disputes clause. ${ }^{25}$

As with other decisions concerning the authority of a board of contract appeals, in this case the determination of whether a collateral-estoppel effect should be given a board finding must spring from deeper considerations of the purpose of the disputes clause and the role of the board as an adjudicative body. Inasmuch as the disputes clause was aimed at avoiding litigation, giving collateral estoppel effect to the board finding would serve that purpose by precluding relitigation in the courts. Such a holding would accord with the Supreme Court's concern for "needless duplication of evidentiary hearings and a heavy additional burden in the time and expense required to bring litigation to an end."26

Arguments may be presented, however, which militate strongly against thus interpreting the board's authority. Initially, it must be recognized that a strict analogy to the application of collateral estoppel in courts and regular administrative agencies ${ }^{27}$ is unwarranted. The boards' authority to decide disputes is, unlike that of regular administrative agencies, not derived from a legislative act but is purely contractual. ${ }^{28}$

Critics have argued that the Supreme Court's characterization of the agreement as mutually voluntary is illusory, for the only real alternative to acceptance of the disputes provision is not to contract at all. ${ }^{29}$ As such, there is a need for strict construction of the extent

"See Schultz, Wunderlich Revisited: New Limits on Judicial Review of Administrative Determination of Government Contract Disputes, 29 LAW \& ConTEMP. ProB. 115, 117 (1964).

${ }_{20}$ The Supreme Court noted that: "Respondent has not argued in this Court that the underlying controversy in the present suit is beyond the scope of the 'disputes' clause in the contract or that it is not governed by the quoted language in the Wunderlich Act :" 373 U.S. at 714.

${ }^{20} \mathrm{Id}$. at 717.

${ }^{27}$ The dissenting judge in $U t a h$ indicated that collateral estoppel should be applied to board decisions just as it is applied to decisions of independent administrative agencies. 339 F.2d at 618 .

${ }^{28}$ See Shedd, supra note 2 , at 73.

${ }^{20}$ For a discussion of the contractor's plight, see Hearings on S. 2487 Before a Subcommittee of the Senate Committee on the Judiciary, 82d Cong., 2d Sess. 54.56 (1952). One alternative to refusing to bid would be to increase the estimate by an amount large enough to cover possible risks arising from unfavorable interpretations. Hearings on S. 2487 Before a Subcommittee of the Senate Committee on the Judiciary, 82 Cong., 2d Sess. 71-72 (1952). 
to which the contractor has waived his judicial remedies. Moreover, unlike the usual private contract arbitral system in which a disinterested party is chosen to decide the controversy, ${ }^{30}$ the board member in a disputes clause proceeding is an appointee of and compensated by only one of the contracting parties. ${ }^{31}$

Perhaps the aspect of the board proceedings most readily assailable, for the purposes of administrative finality, is the absence of statutory provisions ${ }^{32}$ for procedural uniformity in the conduct of the hearings or for the conventional judicial safeguards. ${ }^{33}$ The boards are exempt from the Administrative Procedure Act ${ }^{34}$ and, thus, not bound by its hearing reqiurements. ${ }^{35}$ The boards lack authority to subpoena witnesses, ${ }^{36}$ to compel the production of documents $^{37}$ or to cause depositions to be taken for purposes of discovery; $;^{38}$ use of all these devices might be important to the proper presentation of a contractor's claim. ${ }^{39}$ Furthermore, the boards have no statutory authority for administering the oath. ${ }^{40}$ In addition, the

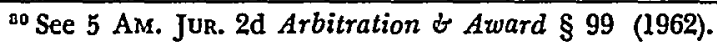

12 The rules of some departments provide expressly for the appointment of board members from within the department ranks. See, e.g., 7 C.F.R. $\$ 1.103$ (a) (Supp. 1965) (Department of Agriculture); 41 C.F.R. $\$ 2.60 .101$ (1964) (Federal Aviation Agency).

32 it must be noted that several boards publish detailed rules of procedure. See Schultz, supra note 24, at 128.

${ }^{33}$ See Volentine \&: Littleton v. United States, 136 Ct. Cl. 638, 641-42, 145 F. Supp. 952, 954 (1956).

34 60 Stat. 237 (1946), 5 U.S.C. \$ 1001 (a) (1958). Section 2 (a) excludes from the operation of the Act "agencies composed of representatives of the parties . . . to the disputes determined by them."

${ }^{35}$ Ibid. Section 7 (b) stipulates that the hearing powers of hearing officers include powers to administer oaths and affirmations, issue subpoenas authorized by law, take or cause depositions to be taken, and to regulate course of the hearing. 60 Stat. 241 (1946), 5 U.S.C. $\$ 1006$ (b) (1958). Section 11 provides for the appointment of hearing examiners. They are to be appointed pursuant to civil service laws, removable only for good cause established and determined by the Civil Service Commission. The examiners are to receive compensation per civil service ratings. 60 Stat. 244 (1946), 5 U.S.C. $\$ 1010$ (1958).

30 1 McBride \& Wachtel, Government Contracts $\$$ 6.10[5] (1965). A department could invoke, however, the cumbersome and seldom-used power afforded by 16 Stat. 412 (1871), 5 U.S.C. $\S 94$ (1958), which enables a department head to apply to any judge or clerk of a United States court for issuance of a subpoena for a witness within the jurisdiction of such court when a claim against the United States is properly pending.

${ }^{37}$ See Schultz, supra note 24 , at 128.

${ }^{88} \mathrm{Id}$. at 128 n.59.

30 For a factual situation in which the subpoena was necessary to protection of a contractor's rights, see Note, United States v. Carlo Bianchi \& Co.: Finality Under the Disputes Clause, 39 N.Y.U.L. REv. 290, 311 n.100 (1964) and accompanying text.

' Ibid. As a substitute, some presiding board members read 62 Stat. 698 (1948), 18 U.S.C. $\$ 287$ (1958) (False Claims Act) or 62 Stat. 749 (1948), 18 U.S.C. $\$ 1001$ (1958) (False Statements Act) to each witness when he takes the stand. See Schultz, supra note 24 , at 128 n.58. 
evidentiary requirements of some of the boards fall short of strict judicial requirements. ${ }^{41}$ The House Report ${ }^{42}$ accompanying the Wunderlich Act recognized the boards' procedural weaknesses and indicated that retention of the finality clauses could be justified only if "hearing procedures were conducted in such a way as to require each party to present openly its side of the controversy and afford an opportunity of rebuttal."43 It was believed that adoption of the reviewing - standard "supported by substantial evidence"44 would correct this situation. ${ }^{45}$

The Utah decision reflects an effort by the Court of Claims to preserve that combination of agency-judicial remedies which it feels is necessary to protect the private contractor. The court permitted the contractor to pursue the administrative remedy provided in the contract without jeopardizing his subsequent judicial cause of action for breach of contract. By refusing to give collateral-estoppel effect to the board's factual determination, the court thwarted an effort to lend judicial status to an essentially non-judicial body. ${ }^{46}$ Though a contrary decision would avoid repetitious litigation, Utah is justified because of the need for strictly construing a clause waiving judicial remedies which must be accepted by anyone contracting with the government and because of the danger of an inadequate board hearing. In the absence of Congressional action prescribing uniform procedural safeguards for the board hearings, the corrective impact of the Wunderlich Act and the Bianchi decision will not suffice $^{4 \tau}$ to render the hearings sufficiently analogous to judicial proceedings to warrant giving collateral estoppel effect to their findings of fact.

\footnotetext{
\$1 See, e.g., 38 C.F.R. $\S 1.773(\mathrm{x})$ (3) (ii) which provides: "The rules of evidence ordinarily observed in Judicial Proceedings will not be strictly followed." (Veterans Administration Contract Appeals Board Procedures); Note, 52 GEo. L.J. 189, 193 (1964). 12 House Comm. on the Judiciary, Finality Clauses in Government Contracts, H.R. REP. No. 1980, 83d Cong., 2d Sess. (1954).

${ }^{48}$ Id. at $4-5$.

468 Stat. 81 (1954), 41 U.S.C. § 321 (1958).

"s House REPORT, supra note 42, at 5. See Spector, Is It "Bianchi's Ghost"-or "Much Ado About Nothing"?, 29 LAW \& CoNTEMP. ProB. 87, 93 (1964).

The Bianchi decision, which placed so much emphasis ou the necessity for a complete administrative record, will conceivably afford another impetus for eliminating the procedural defects.

10 See 1 McBRIDE \& WACHTEL, op. cit. supra note 36, at § 5.60[3].

"See Note, United States v. Carlo Bianchi \& Co.: Finality Under the Disputes Clause, 39 N.Y.U.L. REv. 290, 314-16 (1964).
} 